\title{
Discussion on the Connotation Construction of Applied Undergraduate Colleges*
}

\author{
Xiaoyu Wang \\ Heihe University \\ Heilongjiang, China 164300
}

\author{
Hongwei Yao \\ Heihe University \\ Heilongjiang, China 164300
}

\author{
Liangshuang Tan \\ Heihe University \\ Heilongjiang, China 164300
}

\begin{abstract}
Applied undergraduate colleges and universities are important parts of higher education in China. They have cultivated a large number of applied talents for the prosperous regional economy, and have continuously achieved better University functions through transformation and development. In the course of the transformation and development of application-oriented undergraduate colleges and universities, we should focus on the connotation construction, clarify the basic ideas of connotation construction, and promote the connotation construction of application-oriented undergraduate colleges by innovating the internal management mechanism of universities and constructing scientific and reasonable evaluation mechanisms. It is helpful to train qualified applied talents.
\end{abstract}

Keywords-applied-type undergraduate colleges and universities; talent development system

\section{INTRODUCTION}

Over the past 40 years of reform and opening up, China has achieved world-renowned achievements in economy. China has become the world's second largest economy and the largest trading nation, and has become an important force in promoting the growth of world economy. China's position in the world economy has been steadily improved. At the same time, China's economy is shifting from highspeed growth to high-quality development, and faces important tasks such as restructuring, stabilizing the growth, and controlling the risks. At present, the evolution of the international economic structure is more complicated, making the external environment of China's economic development full of uncertainties. In this context, the Chinese government is further deepening the reform and opening up, implementing innovation-driven development, "The Belt and Road", "Widespread entrepreneurship and innovation", "Internet plus", "Made in China 2025" and other major national strategies to accelerate the transformation of the economic development mode, promote industrial transformation and upgrading, create new growth

*Fund Project: Education Science Planning Project of Heilongjiang Province, Project No.: GBC1317094

School level project of Heihe University, project number: JYZ201902. poles for the economy, making China's economic growth more stable and promoting the endogenous economic growth of China's economy.

The transformation of China's economy from high-speed growth to high-quality development requires valuable human resources as an important supporting force. It needs applied scientific research talents, technical and skilled talents. This will force China's higher education to reposition itself in the "new era". The higher education should take connotation construction as the focus, innovate the talent training system, and cultivate applied talents that meet the requirements of the employers, in order to better perform university functions. Applied undergraduate colleges are an important part of China's higher education. They cultivate a large number of applied talents for the prosperity of regional economy, and continue to transform and develop to better realize their university functions. However, in the process of the colleges' transformation and development, problems such as unclear ideas, unclear policies, unscientific evaluation of effects, etc of the connotation construction have appeared. It is necessary for the domestic theoretical realm to conduct indepth researches, explore solutions and promote the transformation and development of applied undergraduate colleges.

\section{THE BASIC IDEAS OF CONNOTATION CONSTRUCTION}

\section{A. The Application-oriented School Orientation of Applying} What Is Learned

The Ministry of Education clearly stipulates in the relevant documents of undergraduate education and teaching evaluation that the school orientation generally includes five aspects: school goal orientation, school type orientation, education level orientation, subject professional orientation and service scope orientation. At present, most of the applied undergraduate colleges in China are new universities established after the reform and opening up and local universities that were established to meet the needs of local economic development. The school goal of these colleges is to cultivate applied talents that can serve the local economy 
or the regional economy and have the professional ability to adapt to the grassroots and sites, first-line production, service, and management; the setting of disciplines and majors is oriented to the local economic development needs or the industries' demands for talents; These universities mainly carry on undergraduate education, at the same time conducting higher vocational education and a little postgraduate education [1].In short, applying what is learned is the mission and basic orientation of applied universities.

\section{B. The Setting of Disciplines and Majors Oriented to Industry Demands}

The historical background and social background of applied undergraduate colleges determine that these colleges must adapt to the changes in industrial structure promoted by China's economic reforms and the demand for talents in the rapid development of local economy. Therefore, the discipline and specialty setting in applied universities must meet the needs of local and regional economic development, achieve the reasonable discipline and specialty layout and cultivate talents that are urgently needed by local industries, to guarantee the source of students for the majors and the construction of various majors [2].

\section{Teaching System Focusing on Practical Teaching and Cultivating Application Ability}

The cultivation of applied talents needs to be realized through experimental and practical teaching. The distinctive feature of applied teaching is that it is an ability-based teaching system, which enables students to acquire the knowledge, ability and quality needed to adapt to grassroots jobs through the teaching behavior process. The teaching standard and the teaching goal determine that the design of the teaching system should be: while ensuring the subject knowledge, the system must emphasize the cultivation of professional ability; it is necessary to not only ensure the theoretical curriculum but also pay attention to the cultivation of technical and practical skills. Therefore, in the curriculum system setting, in addition to the theoretical curriculum system, practical teaching links and practical teaching systems play an important part in the entire curriculum system.

The cultivation of practical ability should run through the whole process of applied talent training, which is an important part of the talent training system and the main line in the teaching system. The cultivation of ability is the focus of the instructional design; In the teaching of theory courses, whether the course can inspire and train students' ability to analyze and solve problems, and whether the teacher can introduce new ideas, new technologies and new management methods to students in class is an important indicator for evaluating the quality of theoretical teaching; whether the topic of the graduation design (thesis) is related to social reality, whether it has application value, and whether the graduation design (thesis) can reflect the application ability of students to apply professional knowledge to solve practical problems is an important criterion for assessing the graduation design (thesis).

\section{The Faculty with Application Skills and Practical Experience}

Teachers are responsible for teaching, and they are the most important element in the application-oriented talent development system. The application-oriented teaching system needs to be designed and implemented by teachers with application skills and practical experience. The teachers with both teaching skills and practical experience can be called "double-position" teachers. The diversification of source channels of teachers is an effective way to realize the "double-position" teacher team[1]. The approaches of diversification include: hiring personnel with teacher qualities as teachers from the front line of production, service, and management, and hiring a group of people with practical experience as part-time teachers from social enterprises and institutions; in addition, designating a batch of teachers with solid theoretical foundation and certain practical abilities to go to enterprises to work, to improve their knowledge about business management and increase their practical experience, and enrich their life experience. In short, the faculty who can undertake and realize the application-oriented teaching tasks is the key to determining the school orientation and quality of applied universities and colleges.

\section{E. Industry-University-Research Collaboration Education as the Regular Talent Training Mode}

In theory, people all recognize and accept that the Industry-University-Research collaboration education is an important way to train modern talents. Whether the applied universities or other types of universities, they all emphasize the cooperation between schools and enterprises and promote the mode of Industry-University-Research Collaboration. Since the reform and opening up, the reform of higher education has promoted the Industry-University-Research collaboration education in various colleges and universities, and the collaboration education has achieved certain results. Different colleges and universities, according to their own characteristics and educational needs, carry out different aspects of educational cooperation with different social and industrial enterprises and institutions. Some focus on student internship, training, graduation design and social practice, and some focus on scientific research, technology research and development, education and training.

\section{ThE SAFEGUARD MEASURES FOR CONNOTATION CONSTRUCTION}

\section{A. Constructing a Scientific and Reasonable Evaluation Mechanism}

Applied undergraduate colleges and universities realize the connotative development of themselves by defining the school orientation, rationally setting up the disciplines and majors, constructing the teaching system that emphasizes practical application ability, cultivating teachers, and innovating the talent training mode, but constructing a scientific and rational evaluation mechanism is the fundamental guarantee for achieving connotative development [3]. Governments, industry enterprises, universities, and students are all the evaluation mechanism 
subjects for the connotation construction of colleges and universities. Multiple parties participating in the evaluation can make the results more objective and reliable. The design of the evaluation mechanism can follow the whole process of application-oriented personnel training, scientifically formulate evaluation indicators, reasonably set the weights of each evaluation subject, appropriately increase the evaluation weights of employers, use scientific information technology, Internet technology and big data analysis to scientifically and objectively evaluate the performance of connotative development of local undergraduate colleges and universities, gradually change the status quo that as the subjects of talent cultivation, colleges and universities evaluate themselves, and change the subjectivity and arbitrariness of evaluation by constructing a scientific and reasonable evaluation mechanism.

\section{B. Innovating Internal Management Mechanism of Colleges and Universities}

The internal management mechanism is an important basis for the cultivation of talents in colleges and universities, which significantly affects the efficiency and effectiveness of personnel training. Since the internal management mechanism involves various departments such as teaching units, administration, and logistics, and the responsibilities and functions of the departments are often intersected and overlapped, it is difficult to achieve coordination among departments, leading to the separation, poor communication of information, unclear powers and responsibilities of the multiple participation subjects in the connotation construction of colleges and universities, hindering the highquality development of university connotation construction. In the new era, applied undergraduate colleges should further clarify the functions and responsibilities of various subjects such as the school party committee, principal, administrative departments, academic committee, teaching and steering committee, and the faculty and workers' congress, and make them perform their own duties and individually responsible for the development of different undertakings of the school. Therefore, application-oriented undergraduate colleges should innovate the internal management system, and the powers and responsibilities of each department should be clear. The departments should share information and coordinate with each other after they have completed their tasks, and jointly accomplish the tasks of connotation construction, thus improving the talent training quality of applied undergraduate colleges.

\section{Strengthening the Construction of Featured Disciplines}

The discipline is an important carrier and platform for talent training in applied undergraduate colleges. Disciplinary construction has always been at the strategic and overall center in various tasks of colleges and universities. It is an important driving force for the connotation construction of colleges and universities and the key to promoting the high-quality development of university connotation construction. Under the background of China's construction of "double first-rate", well-known universities have launched high-level university construction plans. The importance of discipline construction is self-evident, and the fundamental status of the discipline has been generally emphasized. The applied undergraduate colleges should pay more attention to their dominant and characteristic disciplines in the process of discipline construction, form dislocation competition with well-known universities, and enhance the competitiveness of disciplines in the construction of featured disciplines to promote the connotation construction of applied undergraduate colleges.

\section{Constructing a New Mechanism of Industry-University- Research Collaboration}

The foundation of the connotation construction of applied undergraduate colleges is to cultivate qualified applicationoriented talents. Application-oriented talents should have a solid theoretical foundation and rich practical experience. A solid theoretical foundation can be achieved by studying in schools, but the rich practical experience is difficult to obtain through school study, and it is necessary for the schools and enterprises to cooperate to complete the task of cultivating talents [4]. In fact, the fundamental reason why students do not meet the needs of the society in most cases lies in the lack of roles of the industry enterprises in the process of cultivating talents. The enterprises do not really participate in the process of educating people in colleges and universities, resulting in the little practical experience of talents cultivated by applied undergraduate colleges, and the graduates can not meet the requirements of industry enterprises for talents. Therefore, the new mechanism of Industry-UniversityResearch Collaboration is an important part of the connotation construction of applied undergraduate colleges. In the new mechanism, the role of the government is indispensable. The government should act as the core force in the new mechanism, accelerate the process of industryuniversity-research cooperation through strong policy measures, and guide enterprises to actively participate in the process of educating students in colleges and universities. The guild is an indispensable part of the new mechanism. It is the bridge between the application-based undergraduate universities and enterprises, promoting the sharing of resources and information between universities and enterprises, and jointly cultivating applied talents.

\section{E. Reconstructing the Curriculum System}

To achieve the connotation construction of applied undergraduate colleges, we should make continuous reforms and innovations to break through the existing traditional discipline framework system, closely combine social requirements and corporate job requirements, and reconstruct the curriculum system with curriculum construction as the starting point. The traditional curriculum system generally includes modules of public courses, professional courses, professional elective courses, innovation and entrepreneurship courses, etc. These modules enable students to well master the basic professional knowledge, but such modules are not conducive to the intersection and integration of disciplines. Students' scope of knowledge can not be well expanded, and they are possibly unable to meet the requirements of future social intelligence and information development. Through the reconstruction of the curriculum system, change the situation that public courses are mostly 
the general courses of university foreign languages, university Chinese, etc., add courses in art, culture, logic, etc; increase the proportion of experiments and practice in professional courses, accelerate the construction of integrated bases for internships and employment, and promote the school-enterprise cooperation to go deeper, the two sides' share of resources, mutual benefit and win-win results; add new business concepts and related courses in innovation and entrepreneurship courses, change the current situation of counselors and professional teachers giving lectures in innovation and entrepreneurship classes, hire entrepreneurs as lecturers, and focus on actual combat instead of theories to improve students' overall quality and ability.

\section{CONCLUSION}

In the process of transformation development, applied undergraduate colleges and universities should highlight the school orientation of applying what is learned, the industrial demand oriented setting of disciplines and majors, enhance practical teaching and cultivating application ability, construct a scientific and reasonable evaluation and management mechanism, strengthen the construction of featured disciplines and realize connotative development by constructing a talent cultivation mode of industry-Universityresearch collaboration to provide a powerful talent guarantee for economic and social development of China.

\section{REFERENCES}

[1] Han Yanming.Strategies and Tactics for the Out of Dilemma and Scientific Development of Newly Established Undergraduate Colleges in China[J].China Higher Education Research,2011,(6): pp.59-62.

[2] Liu Yinfang. The orientation and strategy of connotation construction in local applied undergraduate colleges [J] Heilongjiang Researches on Higher Education 2012, (8): (pp.65-67)

[3] Wu Chonghan. Transformation to Applied Undergraduate Universities: The Nature of Knowledge Labor and Connotation Construction [J] Vocational and Technical Education, 2016(3): p59.

[4] Chen Jing. The role transformation of the evaluation subject of the talent training quality of applied-oriented colleges and universities under the perspective of improvement. [J] Modern Education Science. 2017(5): pp.90-93.

[5] Liu Liangjun, Zhang Baolong. Reform and innovate connotation development and construct applied undergraduate colleges $[\mathrm{N}]$. China Education Daily. 2017-06-07. 